\title{
Impact of casein and egg white proteins on the structure of
}

\section{wheat gluten-based protein-rich food}

\author{
Arno G.B. Wouters*, Ine Rombouts, Bert Lagrain ${ }^{\mathrm{b}}$, Jan A. Delcour \\ Laboratory of Food Chemistry and Biochemistry and Leuven Food Science and Nutrition \\ Research Center (LFoRCe), Katholieke Universiteit Leuven, Kasteelpark Arenberg 20, B- \\ 3001 Leuven, Belgium \\ ${ }^{b}$ Present address: Centre of Surface Chemistry and Catalysis, KU Leuven, Kasteelpark \\ Arenberg 23, B-3001 Leuven, Belgium
}

*Corresponding author.

Tel.: +32 (0) 16372035

E-mail address: arno.wouters@biw.kuleuven.be

This article has been accepted for publication and undergone full peer review but has not been through the copyediting, typesetting, pagination and proofreading process, which may lead to differences between this version and the Version of Record. Please cite this article as doi: $10.1002 /$ jsfa. 7143

This article is protected by copyright. All rights reserved 


\section{ABSTRACT}

BACKGROUND: There is a growing interest in texturally and nutritionally satisfying vegetable alternatives for meat. Wheat gluten proteins have unique functional properties but a poor nutritional value in comparison to animal proteins. This study investigated the potential of egg white and bovine milk casein with well-balanced amino acid composition to increase the quality of wheat gluten-based protein-rich foods.

RESULTS: Heating a wheat gluten $(51.4 \mathrm{~g})$ - water $(100.0 \mathrm{ml})$ blend for 120 minutes at 100 ${ }^{\circ} \mathrm{C}$ increased its firmness less than heating a wheat gluten $(33.0 \mathrm{~g})$ - freeze dried egg white $(16.8 \mathrm{~g})$ - water $(100.0 \mathrm{ml})$ blend. In contrast, the addition of casein to the gluten-water blend negatively impacted firmness after heating. Firmness was correlated to loss of protein extractability in sodium dodecyl sulfate containing medium during heating, which was higher with egg white than with casein. Even more, heat-induced polymerization of the gluten-water blend with egg white but not with casein was larger than expected from the losses in extractability of gluten and egg white on their own.

CONCLUSION: Structure formation was favored by mixing gluten with egg white but not with casein. These observations were linked to the intrinsic polymerization behavior of egg white and casein, but also to their interaction with gluten. Thus, not all nutritionally suitable proteins can be used for enrichment of gluten-based protein-rich foods.

Keywords: Egg white; Wheat Gluten; Casein; Protein interactions; Nutritional quality; Texture 


\section{INTRODUCTION}

Since 1950, the world population increased from 2.5 to over 7 billion people. The United Nations estimates a further growth to over 9 billion people by 2050. A large part of this increase will take place in third world countries ${ }^{1}$ where the improving standard of living will have profound implications on food consumption. This will include a gradual transition from vegetable to animal protein in the $\operatorname{diet}^{2}$ Meat products have enjoyable organoleptic properties as well as a generally more favorable amino acid profile than vegetable protein sources. ${ }^{3 ;} 4$ However, meat production generates between 10 and $51 \%$ of the worldwide emission of greenhouse gases. ${ }^{5 ; 6}$ This alone justifies the search for vegetable alternatives for meat. ${ }^{7}$

Most of the dry matter of meat consists of protein and protein plays a key role in giving meat its desired structure and texture. ${ }^{3 ; 8}$ An important challenge in the production of meat analogs is to provide them with satisfying texture.

The storage protein of wheat is referred to as gluten. It is not soluble in water and upon mixing with water forms a visco-elastic network and an even stronger three-dimensional network when heated. ${ }^{9}$ Wheat gluten's functional properties and its availability as co-product of industrial wheat starch isolation ${ }^{10}$ make it a useful starting material for meat analogs. However, it should be mentioned that a minority of the population, suffering from celiac disease or non-celiac gluten sensitivity, must completely ban gluten proteins from their diet. $^{11 ;} 12$ These wheat gluten-based meat analogs can be prepared by extrusion ${ }^{13}$ or heating. Seitan is a popular vegetarian protein-rich food made by heating wheat gluten. ${ }^{14}$ Despite its commercial importance, scientific literature about this particular product is scarce.

Whereas meat products have a favorable amino acid profile ${ }^{4}$, this is not the case for gluten proteins, with Lys and, to a lesser extent, Thr as limiting amino acids. ${ }^{3 ;} 15$ Enrichment of gluten with other non-meat proteins can increase its nutritional quality. Combining cereal with oilseed or legume proteins ${ }^{7}$ yields a well-balanced amino acid profile and desirable 
product textures. Blends of wheat gluten and soy have been used in extrusion processes ${ }^{16}$ as have blends of wheat gluten and pea proteins, i.e. arrum. ${ }^{17}$ In such mixtures, gluten proteins are considered to be responsible for the meat-like fibrous structure. ${ }^{18 ;} 13$ While egg white protein is extensively used in a variety of applications, its application in wheat gluten-based blends has to the best of our knowledge not been reported. Bovine casein, which can be produced industrially by acid coagulation from milk and is used in various food and non-food applications ${ }^{3}$, has also not been investigated in this context.

Protein cross-linking can take place during heating and is critical for food structure formation. ${ }^{19}$ Different protein cross-links have been detected in food. They include disulfide (SS) and isopeptide bonds and cross-links originating from dehydroproteins, tyrosine, or Maillard reactions. ${ }^{20} \mathrm{SS}$ bonds are the most important gluten cross-links formed during moderate heating. At high temperature and/or $\mathrm{pH}$, the dehydroalanine-derived cross-links lanthionine (Lan) and lysinoalanine (Lal) are also formed. ${ }^{21}$ Besides its impact on structure, Lal formation decreases Lys levels and thereby the nutritional quality.

To create wheat gluten-based protein-rich foods enriched with other proteins with satisfying structural and nutritional quality, a fundamental understanding of interactions between the different proteins is necessary. Against this background, we investigated whether seitan-like protein mixtures consisting of gluten on the one hand and egg white or casein from bovine milk on the other hand form a good basis for protein-rich foods with favorable texture and nutritional properties. The texture of wheat gluten-based protein blends, in some cases enriched with various nutritionally suitable protein fractions, was compared with that of chicken breast muscle as a benchmark. The heat-induced protein cross-linking was investigated to understand protein structure formation. Heat-induced changes in isolated proteins were compared to those in their mixtures.

This article is protected by copyright. All rights reserved 


\section{MATERIALS AND METHODS}

\section{Materials}

Chicken breast muscle meat (further referred to as chicken meat) and fresh chicken eggs were purchased in a local supermarket. Commercial wheat gluten was obtained from Syral (Aalst, Belgium). Casein from bovine milk and all chemicals, solvents and reagents were from Sigma-Aldrich (Bornem, Belgium) unless indicated otherwise. Lan and Lal standards for amino acid analysis were from TCI Europe (Zwijndrecht, Belgium) and Bachem (Weil am Rhein, Germany), respectively.

\section{Sample preparation}

For texture analysis, chicken meat was used as is. For other analyses it was homogenized in a blender (Braun, Kronberg im Taunus, Germany), freeze-dried and passed through a $250 \mu \mathrm{m}$ sieve. The freeze-dried sample contained $0.923 \mathrm{~g} / \mathrm{g}$ protein content on dry matter basis $(\mathrm{db})$. Protein content ( $\mathrm{N}$ x 5.7 for gluten and $\mathrm{N}$ x 6.25 for the other proteins) was determined using an adaptation of the $\mathrm{AOAC}^{22}$ Official Method to an automated Dumas protein analysis system (EAS Variomax N/CN Elt, Gouda, The Netherlands). Egg white was separated from egg yolk, freeze-dried and passed through a $250.0 \mu \mathrm{m}$ sieve $(0.896 \mathrm{~g} / \mathrm{g}$ protein content, $\mathrm{db})$. Casein from bovine milk $(0.903 \mathrm{~g} / \mathrm{g}$ protein content, $\mathrm{db})$ was passed through a $250.0 \mu \mathrm{m}$ sieve prior to further use. Commercial wheat gluten $(0.833 \mathrm{~g} / \mathrm{g}$ protein content, $\mathrm{db})$ was dry blended in a head-over-head shaker for $24 \mathrm{~h}$ with freeze-dried egg white or casein. The ratio of gluten to egg white or casein was $1.8: 1$ on a dry matter protein basis. The dry protein blends are further referred to as gluten-ew and gluten-cas respectively.

This article is protected by copyright. All rights reserved 


\section{Heating}

For heating prior to texture analysis, chicken meat was used as is, while wheat gluten-based protein blends with protein and moisture contents similar to those of chicken breast muscle were prepared by mixing a total protein mass of $71.5 \mathrm{~g}$ of wheat gluten, gluten-ew or glutencas with $178.6 \mathrm{ml}$ of water (ratio of protein to water of $1: 2.5$ ) in a $100.0 \mathrm{~g}$ pin mixer (National Manufacturing, Lincoln, NE, USA) for 13 min. Chicken meat and wheat gluten-based protein blends were then boiled at $100^{\circ} \mathrm{C}$ for $120 \mathrm{~min}$ and samples were withdrawn after $0,5,10,20$, $35,45,55$ and $120 \mathrm{~min}$.

For size exclusion high performance liquid chromatography (SE-HPLC) and amino acid analysis, wheat gluten, egg white, casein and dry protein blends (gluten-ew, gluten-cas) were heated for $120 \mathrm{~min}$ in a water bath at $100{ }^{\circ} \mathrm{C}$. The ratio of protein to water during heating was $1: 30$

\section{Texture analysis}

Firmness of full chicken breast muscle and wheat gluten-based protein blends was evaluated with a standardized pressure test based on Cavitt et al. ${ }^{23}$, Christensen et al. ${ }^{24}$ and Lyon et al. ${ }^{25}$ From each sample, 6 strips of $5.0 \times 1.0 \times 1.0 \mathrm{~cm}$ were cut. The force $(\mathrm{N})$ needed to compress a sample to $40 \%$ of its initial thickness was measured with an Instron (Norwood, MA, USA) 3343 using a rectangular blade (70.0 $\mathrm{mm}$ width and $3.0 \mathrm{~mm}$ thickness) moving down at a speed of $5.0 \mathrm{~mm} / \mathrm{s}$ and is further referred to as firmness. The firmness was regarded as zero for samples from which no strip could be cut out.

\section{Size exclusion high performance liquid chromatography}

This article is protected by copyright. All rights reserved 
(Un)heated samples were extracted $(1.0 \mathrm{mg}$ per $\mathrm{mL}$ of solvent) with $0.05 \mathrm{M}$ sodium phosphate buffer ( $\mathrm{pH}$ 6.8) containing $20 \mathrm{~g} / \mathrm{L}$ sodium dodecyl sulfate (SDS). To evaluate extractability under reducing conditions, extraction was carried out under $\mathrm{N}_{2}$ atmosphere in the same SDS buffer, now also containing $10 \mathrm{~g} / \mathrm{L}$ dithiothreitol (DTT). Protein extracts were analyzed by SE-HPLC as described by Lagrain et al. ${ }^{26}$ using a Shimadzu (Kyoto, Japan) LC$2010 \mathrm{HT}$ system with protein elution monitoring at $214 \mathrm{~nm}$.

After centrifugation (10 min, $10000 \mathrm{~g}$ ) and filtration (Millex-GP, $0.45 \mu \mathrm{m}$, polyethersulfone; Millipore, Carrightwohill, Ireland) samples $(60.0 \mu \mathrm{l})$ were loaded on a Biosep-SEC-S4000 column (separation range from 15 to $500 \mathrm{kDa}$, Phenomenex, Torrance, CA, USA). The elution solvent was acetonitrile - MilliQ water $(1: 1, \mathrm{v} / \mathrm{v})$ containing $0.5 \mathrm{~g} / \mathrm{L}$ trifluoroacetic acid. The flow rate was $1.0 \mathrm{~mL} / \mathrm{min}$ and the temperature $30{ }^{\circ} \mathrm{C}$. The amount of proteins extractable in SDS containing buffer, further referred to as SDSEP, was calculated from the area under the SE-HPLC chromatogram and expressed as a percentage of the total amount of protein, i.e. the amount of extractable proteins from the corresponding unheated sample under reducing conditions.

\section{Amino acid analysis}

Amino acids and the amino acid cross-links Lal and Lan were liberated by acid hydrolysis and separated by high-performance anion-exchange chromatography with integrated pulsed amperometric detection (HPAEC-IPAD) as described by Rombouts et al. ${ }^{27}$. Samples (10.0 $\mathrm{mg}$ of protein, $\mathrm{db}$ ) were hydrolyzed in $1.0 \mathrm{~mL}$ of $6.0 \mathrm{M} \mathrm{HCl}$ containing $1.0 \mathrm{~g} / \mathrm{L}$ phenol and 3.0 $\mathrm{mM}$ norleucine (as internal standard) while heating at $110^{\circ} \mathrm{C}$ for $24 \mathrm{~h}$. Reaction mixtures were subsequently diluted (200-fold) in deionized water and filtered (Millex-GP, $0.22 \mu \mathrm{m}$, polyethersulfone; Millipore). Amino acids were separated (injection volume $=25 \mu \mathrm{L}$, flow rate $\left.=0.25 \mathrm{~mL} / \mathrm{min}, 30^{\circ} \mathrm{C}\right)$ on an AminoPac PA10 column $(250 \times 2 \mathrm{~mm}$; Dionex Benelux, 
Amsterdam, The Netherlands) using a Dionex (Sunnyvale, CA, USA) system BioLC equipped with Chromeleon version 6.70 software (Dionex). Gradient conditions and detection waveform were as in Rombouts et al. ${ }^{27}$ Amino acid levels were expressed in $\mu \mathrm{mol} / \mathrm{g}$ protein. To calibrate the method, response factors were determined using standard solutions that contained all amino acids and the internal standard. Correction factors were used to account for incomplete cleavage of peptide bonds involving Val and Ile during acid hydrolysis. Trp is degraded during hydrolysis and could not be quantified.

\section{Statistical analysis}

Heating of all samples was carried out in duplicate. SE-HPLC analyses and amino acid analyses were conducted at least in duplicate and triplicate, respectively. All data was analyzed using statistical software JMP Pro 11, with a Tukey multiple comparison test and the significant difference set at $\mathrm{p}<0.05$.

\section{RESULTS AND DISCUSSION}

\section{Texture analysis of chicken breast meat and gluten-based protein blends}

First, the firmness readings of wheat gluten-based protein blends were compared to those of chicken breast. The force needed to reduce the samples to $40 \%$ of their initial thickness was determined before and after heating for different times at $100{ }^{\circ} \mathrm{C}$. Before heating, the gluten blend had no measurable firmness (Figure 1). In contrast, the anisotropic structure in which chicken proteins are ordered in muscle fibers ${ }^{28}$ provided them with firmness. Manski et al. ${ }^{29}$ emphasized the importance of anisotropy for the texture of food structures. Heating increased firmness significantly $(\mathrm{P}<0.05)$ for both chicken breast and a gluten blend. In the gluten blend, heat-induced strengthening of the protein structure was crucial to obtain a product with satisfying firmness. Figure 2 compares the firmness of chicken breast muscle and gluten- 
based blends with different compositions before and after heating for $120 \mathrm{~min}$ at $100{ }^{\circ} \mathrm{C}$. Whereas no visible differences between the heated protein blends could be noted, the addition of egg white to gluten increased firmness after heating significantly $(\mathrm{P}<0.05)$, while that of casein resulted in a less firm gluten blend $(\mathrm{P}<0.05)$.

These results thus show that different proteins have a different impact on texture formation during heating, which was further investigated in the following sections.

\section{Impact of heating on individual protein fractions}

The polymerization potential of different individual protein fractions was evaluated based on heat-induced changes in protein molecular weight and extractability in SDS containing medium.

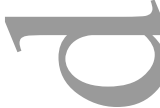

SDSEP readings of gluten before and after heating were $82 \%$ and $36 \%$, respectively (Figure 3A). A part of the unheated gluten was not extractable. Heating formed even more nonextractable protein compounds ${ }^{30}$. Reduction of SS bonds by DTT almost fully restored the SDSEP content of heated gluten (Figure 3A, right), indicating that most non-extractable compounds formed during heating resulted from further SS cross-linking.

Unheated egg white protein had an SDSEP content of 98\% under non-reducing conditions (Figure 3B, left). Heating egg white lowered its SDSEP content to nearly zero (Figure 2B, left), and the addition of reducing agent to the extraction medium did not restore it (Figure $2 \mathrm{~B}$, right). The SDSEP results demonstrate that the extent of network formation and the contribution of non-SS cross-links hereto is larger in egg white than in gluten.

Unheated casein was also fully extractable (Figures 2C; left). Heating casein decreased the SDSEP content neither under non-reducing (Figure 2C, left), nor under reducing conditions (Figure 2C, right). Nevertheless, shifts in the profiles of casein extracted under non-reducing 
and reducing conditions (Figure 2C, left and right) suggested the formation of extractable oligomers.

Thus, all studied proteins but gluten were almost completely extractable in their native state. Heating for $120 \mathrm{~min}$ at $100{ }^{\circ} \mathrm{C}$ caused protein cross-linking as observed by extractability loss for gluten and egg white, and by an increased level of protein compounds with high molecular weight for casein. The decrease in SDSEP under non-reducing conditions was largest for egg white and nonexistent for casein, implying a larger intrinsic cross-linking potential for egg white proteins. Reducible SS cross-links were very important for network formation, but indications for non-SS cross-links were also found, especially for egg white. Amino acid analysis of different protein fractions before and after heating showed that a significant level of Lan $(9.3 \mathrm{mg} / \mathrm{g}$ protein and Lal $(1.4 \mathrm{mg} / \mathrm{g}$ protein) was formed in egg white proteins, but not in gluten or casein.

\section{Impact of heating on gluten-based protein blends}

In the gluten-based blends, different protein-types co-exist. Texture differences can be related to cross-linking capacities of the isolated protein fractions, but in some cases also to interactions between the different protein fractions. To investigate the latter, heat-induced protein cross-linking of isolated protein fractions was compared with that of mixtures by comparing SDSEP values before and after heating (Table 1). When no interactions between proteins from different sources occur, the SDSEP of a protein mixture would be expected to equal the weighted average of the SDSEP values of the isolated compounds. This calculated value for SDSEP is further referred to as $\operatorname{SDSEP}_{\text {calc }}($ Table 1).

In gluten-ew, experimental SDSEP under non reducing conditions before heating was lower than the anticipated $\operatorname{SDSEP}_{\text {calc }}$ (Table 1). This indicated that gluten and egg proteins 
influenced each other's extractability during mixing. Either gluten decreased the extractability of egg white, egg white decreased the extractability of gluten, or both. Heating then further decreased the SDSEP content. The SDSEP content under non reducing conditions of the heated gluten-ew sample was almost zero and much lower than SDSEP $_{\text {calc }}$ (Table 1). This shows that gluten and egg white protein also impact each other's heatinduced polymerization (Table 1). Egg white proteins were rendered almost completely unextractable upon heating in absence of other proteins (Figure 2C) and appeared to trigger polymerization of gluten proteins in the gluten-ew blend. These findings were confirmed for gluten-ew blends with ratios of gluten to egg white protein ranging from 0.9:1 to 4.5:1 (data not shown). In a similar study, Rombouts et al. ${ }^{31}$ noted that wheat gluten and bovine serum albumin (BSA) impact each other's heat-induced extractability loss, but in an opposite way. The heat-induced extractability loss of a gluten-BSA blend was lower than expected based on that of the isolated compounds. ${ }^{31}$ For gluten-cas, the heat-induced extractability loss was not significantly different $(\mathrm{P}>0.05)$ from the calculated one. Thus, while the heating step induced oligomerization of isolated casein and polymerization of isolated gluten, no indications were found that gluten and casein impact each other's polymerization. All of the above demonstrate that the impact of different protein types on each other's cross-linking behavior is complex. The protein blends used here consist of proteins that are thermodynamically incompatible ${ }^{32}$ before heating, but the impact of heat thereupon may play a role as well. That a reducing agent partially restored extractability in SDS containing medium for both gluten-based mixtures indicates the importance of heat induced SS bond formation. Low levels of Lan (1 mg/g protein) were detected in gluten-ew after heating. This was not the case in gluten-cas.

Thus, heat induced texture properties of protein mixtures can be related to SDSEP losses, but it is important to consider the compatibility of proteins from different solubility classes. 
Network formation during heating led to a firm wheat gluten structure. Addition of egg white protein or casein to wheat gluten respectively increased or decreased heat-induced structure formation. The formation of intermolecular cross-links in and probably between gluten and egg white proteins substantially the increased average molecular sizes of protein components in the system. In contrast, gluten and casein did not impact each other's polymerization. It is therefore hypothesized that the structure is weakened when some of the proteins in a mixture do not take part in the polymerization reactions.

\section{Nutritional value of different protein sources}

Chicken breast muscle proteins have a better nutritional profile than gluten proteins but their respective nutritional values have, to the best of our knowledge, never been compared using the same methodology. Essential amino acids cannot be synthesized de novo and therefore must be supplied by the diet. ${ }^{3 ;} 33$ The amino acid scoring pattern (AASP) of a protein (mixture) describes the degree of match between the levels of essential amino acids and their metabolic demands ${ }^{34}$. It is evaluated by dividing the level of each essential amino acid by its amino acid scoring pattern requirement (AASPR), taking into account its biological value as described by Millward ${ }^{34}$. Table 2 compares the levels of all essential amino acids (except Trp) in wheat gluten, egg white and casein to the levels of their respective metabolic demands and to those of chicken breast muscle. The sulfur-containing amino acids (SAA) Met and Cys can be converted into each other. Likewise, the aromatic amino acids (AAA) Phe and Tyr are considered a single pool of nutritionally equivalent amino acids. For these two groups, amino acid requirements were evaluated as a whole.

The scores of all essential amino acids in chicken breast muscle exceeds 100\% (Table 2B) indicating a favorable profile for human nutrition as mentioned earlier. ${ }^{4}$ In addition, our results largely confirm previously reported levels of essential amino acids in chicken breast 
muscle. Only Phe and Val were significantly lower (Tukey multiple comparison, $\alpha=0.05$ ) than the averages of several values from literature. ${ }^{35}$ The levels of His, Ile, Lys, Met and Thr were lower in gluten than in chicken breast muscle. The results confirmed that Lys is the first limiting amino acid of wheat ${ }^{15}$, with an AASP of $52 \%$. All AASP values of egg white proteins and casein exceeded $100 \%$. For the above mentioned protein blends, theoretical calculations were made based on the AASP values of the individual protein fractions. All theoretical AASP values exceeded 100\% for gluten-ew and gluten-cas (data not shown), except for Lys in gluten-ew. The calculated AASP for Lys in gluten-ew was 87\%, which is still significantly higher than that of wheat gluten proteins.

Heat treatment can induce various reactions which decrease the levels of certain amino acids directly. In this regard, it is of note that our SDSEP results suggest the formation of non-SS cross-links in all samples, and especially in egg white. In gluten, the most known non-SS cross-links are the dehydroalanine-derived cross-links Lan and Lal. The formation of Lal decreases the level of available Lys and hence is important from a nutritional point of view. Furthermore, it has been suggested that lysinoalanine may be toxic. ${ }^{36}$ No Lal or Lan were detected in heated wheat gluten and casein. Relatively high levels of Lan and Lal were detected in egg white protein. In addition, heating decreased Lys levels in egg white protein from an AASP of 149 to $128 \%$. In casein, heating did not decrease Lys levels significantly (P $>0.05)$. However, despite the presence of these non-SS cross-links in heated egg white proteins, only very low levels of Lan (1 mg/g protein) and no Lal were detected in gluten-ew. Also, Lys levels of gluten-ew before and after heating were not significantly different $(\mathrm{P}>$ 0.05). Remarkably, heating negatively impacted the nutritional quality of egg white proteins, but less so of the gluten-ew protein blend.

\section{CONCLUSIONS}

This article is protected by copyright. All rights reserved 
In conclusion, heating increased firmness of a wheat gluten blend as a model for wheat gutenbased protein-rich products. Casein only polymerized to a low extent during heating in absence of other proteins and caused a decrease in firmness in a heated gluten-cas blend. In contrast, egg white protein polymerized quite extensively when heated in absence of other proteins and also seemed to interact with the gluten proteins when heated in a gluten-ew mixture. Firmness of such a heated gluten-ew blend was higher than that of a heated gluten blend without egg white proteins. Thus, not all food proteins can be used in combination with gluten proteins to obtain products of appropriate texture. It is important to take the intrinsic polymerization potential of the individual protein components as well as the interactions between different proteins during food processing into account. Besides the significant differences in texture between different heated protein blends, it should be noted that firmness of all heated blends was still lower than that of a heated chicken breast muscle. Nutritional quality of gluten-based protein-rich products was improved by adding egg white or casein. However, heating slightly decreased the level of Lys in an egg white enriched gluten-based protein-rich product.

\section{ACKNOWLEDGMENTS}

I. Rombouts and B. Lagrain wish to acknowledge the Research Foundation - Flanders (FWO, Brussels, Belgium) and the Industrial Research Fund (IOF, KU Leuven), respectively, for financial support. J.A. Delcour is W.K. Kellogg Chair in Cereal Science and Nutrition at KU Leuven. This work is part of the Methusalem program "Food for the Future" at KU Leuven. 


\section{REFERENCES}

(1) UN, World population prospects: The 2012 revision, key findings and advance tables. United Nations. 54 p. From http://esa.un.org/wpp/Documentation/publications.htm (2013).

(2) Delgado CL, Rising consumption of meat and milk in developing countries has created a new food revolution. $J$ Nutr 133: 3907s-3910s (2003).

(3) Belitz H-D, Grosch W and Schieberle P, Food chemistry, Springer-Verlag, Berlin, Germany, pp. 563-616; 670-745 (2009).

(4) Kim Y-S, Meat production, in Meat science and applications, ed. by Hui, YH, Nip, WK, Rogers, RW and Young, OA, Marcel Dekker, Inc., Basel, Switzerland, pp 563-578 (2001).

(5) Alexandratos N and Bruinsma J, World agriculture: Towards 2030/2050. Prospects for food, nutrition, agriculture and major commodity groups. An fao perspective. Interim report. Food and Agriculture Organisation. 154 p. From http://www.fao.org/economic/esa/esaactivities/perspectives/en/ (2006).

(6) Herrero M, Gerber P, Vellinga T, Garnett T, Leip A, Opio C, Westhoek HJ, Thornton PK, Olesen J, Hutchings N, Montgomery H, Soussana JF, Steinfeld H and McAllister TA, Livestock and greenhouse gas emissions: The importance of getting the numbers right. Anim Feed Sci Technol 166-67: 779-782 (2011).

(7) Asgar MA, Fazilah A, Huda N, Bhat R and Karim AA, Nonmeat protein alternatives as meat extenders and meat analogs. Compr Rev Food Sci F 9: 513-529 (2010).

(8) Tornberg E, Effects of heat on meat proteins - implications on structure and quality of meat products. Meat Sci 70: 493-508 (2005).

(9) Delcour JA, Joye IJ, Pareyt B, Wilderjans E, Brijs K and Lagrain B, Wheat gluten functionality as a quality determinant in cereal-based food products. Annu Rev Food Sci T 3: 469-492 (2012).

(10) Van Der Borght A, Goesaert H, Veraverbeke WS and Delcour JA, Fractionation of wheat and wheat flour into starch and gluten: Overview of the main processes and the factors involved. J Cereal Sci 41: 221-237 (2005).

(11) Guandalini S and Assiri A, Celiac disease: A review. JAMA Pediatr 168: 272-278 (2014).

(12) Mansueto P, Seidita A, D'Alcamo A and Carroccio A, Non-celiac gluten sensitivity: Literature review. J. Am. Coll. Nutr. 33: 39-54 (2014).

(13) Strahm B, Meat alternatives, in Soy applications in food, ed. by Riaz, MN, Taylor \& Francis Group, Boca Raton, Florida, USA, pp 135-154 (2006).

(14) Bettenhausen C, Seitan. Wheat makes a vegetarian alternative for meat. Chem Eng News 91: 32 (2013).

This article is protected by copyright. All rights reserved 
(15) Shewry PR, Improving the protein content and composition of cereal grain. J Cereal Sci 46: 239-250 (2007).

(16) Liu K and Hsieh F-H, Protein-protein interactions during high-moisture extrusion for fibrous meat analogues and comparison of protein solubility methods using different solvent systems. J Agric Food Chem 56: 2681-2687 (2008).

(17) Davies J and Lightowler H, Plant-based alternatives to meat. Nutr Food Sci 98: 90-94 (1998).

(18) Maningat CC, DeMeritt GK, Chinnaswamy R and Bassiri SD, Properties and applications of texturized wheat gluten. Cereal Food World 44: 650-655 (1999).

(19) Singh H, Modification of food proteins by covalent crosslinking. Trends Food Sci Technol 2: 196-200 (1991).

(20) Gerrard JA, Protein-protein crosslinking in food: Methods, consequences, applications. Trends Food Sci Technol 13: 391-399 (2002).

(21) Lagrain B, De Vleeschouwer K, Rombouts I, Brijs K, Hendrickx ME and Delcour JA, The kinetics of beta-elimination of cystine and the formation of lanthionine in gliadin. $J$ Agric Food Chem 58: 10761-10767 (2010).

(22) AOAC. Official methods of analysis. Method 990.03., Association of Official Analytical Chemists: Washington, DC, USA, (1995).

(23) Cavitt LC, Meullenet JFC, Xiong R and Owens CM, The relationship of razor blade shear, allo-kramer shear, warner-bratzler shear and sensory tests to changes in tenderness of broiler breast fillets. Journal of Muscle Foods 16: 223-242 (2005).

(24) Christensen M, Purslow PP and Larsen LM, The effect of cooking temperature on mechanical properties of whole meat, single muscle fibres and perimysial connective tissue. Meat Sci 55: 301-307 (2000).

(25) Lyon BG and Lyon CE, Assessment of three devices used in shear tests of cooked breast meat. Poult Sci 77: 1585-1590 (1998).

(26) Lagrain B, Brijs K, Veraverbeke WS and Delcour JA, The impact of heating and cooling on the physico-chemical properties of wheat gluten-water suspensions. J Cereal Sci 42: 327333 (2005).

(27) Rombouts I, Lamberts L, Celus I, Lagrain B, Brijs K and Delcour JA, Wheat gluten amino acid composition analysis by high-performance anion-exchange chromatography with integrated pulsed amperometric detection. J Chromatogr A 1216: 5557-5562 (2009).

(28) $\mathrm{Au} \mathrm{Y}$, The muscle ultrastructure: A structural perspective of the sarcomere. Cell Mol Life Sci 61: 3016-3033 (2004).

This article is protected by copyright. All rights reserved 
(29) Manski JM, van der Goot AJ and Boom RM, Advances in structure formation of anisotropic protein-rich foods through novel processing concepts. Trends Food Sci Technol 18: 546-557 (2007).

(30) Lagrain B, Thewissen BG, Brijs K and Delcour JA, Mechanism of gliadin-glutenin cross-linking during hydrothermal treatment. Food Chem 107: 753-760 (2008).

(31) Rombouts I, Lagrain B and Delcour JA, Heat-induced cross-linking and degradation of wheat gluten, serum albumin, and mixtures thereof. J Agric Food Chem 60: 10133-10140 (2012).

(32) Polyakov VI, Grinberg VY and Tolstoguzov VB, Thermodynamic incompatibility of proteins. Food Hydrocolloid 11: 171-180 (1997).

(33) Trumbo P, Schlicker S, Yates AA and Poos M, Dietary reference intakes for energy, carbohydrate, fiber, fat, fatty acids, cholesterol, protein and amino acids. J Am Diet Assoc 102: $1621-1630$ (2002).

(34) Millward DJ, Amino acid scoring patterns for protein quality assessment. Br J Nutr 108: S31-S43 (2012).

(35) Soriano-Santos J, Chemical composition and nutritional content of raw poultry meat, in Handbook of poultry science and technology, ed. by Guerrero-Legarreta, I, John Wiley \& Sons, Inc., Hoboken, New Jersey, USA, pp 467-490 (2010).

(36) Friedman M, Chemistry, biochemistry, nutrition, and microbiology of lysinoalanine, lanthionine, and histidinoalanine in food and other proteins. J Agric Food Chem 47: 12951319 (1999). 
Table 1. Theoretical and actual SDSEP values under non-reducing (NRED) and reducing (RED) conditions of gluten-based protein mixtures before and after heating (120 min at 100 $\left.{ }^{\circ} \mathrm{C}\right)$.

\begin{tabular}{|c|c|c|c|c|c|}
\hline & \multirow{2}{*}{$\begin{array}{l}\text { Heating time } \\
\text { (min) }\end{array}$} & \multicolumn{2}{|c|}{ SDSEP $_{\text {calc }}$} & \multicolumn{2}{|c|}{ SDSEP } \\
\hline & & NRED & $R E D$ & NRED & RED \\
\hline \multirow{2}{*}{ Gluten-ew } & 0 & 88 & 100 & 69 & 100 \\
\hline & 120 & 24 & 62 & 2 & 40 \\
\hline \multirow{2}{*}{ Gluten-cas } & 0 & 89 & 100 & 90 & 100 \\
\hline & 120 & 59 & 97 & 59 & 98 \\
\hline
\end{tabular}


Table 2. A. Levels of His, Ile, Leu, Lys, Met, Phe, Thr and Val (mg/g protein) of total chicken breast muscle, wheat gluten, egg white and casein. B. Amino acid requirements and amino acid scoring pattern for His, Ile, Leu, Lys, SAA, AAA, Thr and Val (\%) of total chicken breast muscle, wheat gluten, egg white and casein.

\begin{tabular}{|c|c|c|c|c|c|c|c|c|c|c|}
\hline A & & & & & B & & & & & \\
\hline \multirow[b]{2}{*}{ AA } & \multicolumn{4}{|c|}{ Amino acid levels (mg/g protein) } & \multirow[b]{2}{*}{ AA } & \multirow{2}{*}{$\begin{array}{c}\text { AASP } \\
\text { R } \\
\text { (mg/g } \\
\text { protei } \\
\text { n) }\end{array}$} & \multicolumn{4}{|c|}{ AASP (\%) } \\
\hline & $\begin{array}{c}\text { Chicken } \\
\text { breast } \\
\text { muscle }\end{array}$ & $\begin{array}{l}\text { Wheat } \\
\text { gluten }\end{array}$ & $\begin{array}{l}\text { Egg } \\
\text { white }\end{array}$ & Casein & & & $\begin{array}{c}\text { Chicken } \\
\text { breast } \\
\text { muscle }\end{array}$ & $\begin{array}{l}\text { Wheat } \\
\text { gluten }\end{array}$ & $\begin{array}{l}\text { Egg } \\
\text { white }\end{array}$ & Casein \\
\hline His & $29 \pm 1$ & $22 \pm 1$ & $26 \pm 1$ & $47 \pm 2$ & His & 12 & 246 & 187 & 219 & 390 \\
\hline Ile & $50 \pm 0$ & $39 \pm 1$ & $58 \pm 2$ & $64 \pm 4$ & Ile & 24 & 207 & 164 & 241 & 267 \\
\hline Leu & $74 \pm 0$ & $72 \pm 1$ & $85 \pm 1$ & $110 \pm 6$ & Leu & 47 & 157 & 152 & 181 & 233 \\
\hline Lys & $68 \pm 6$ & $19 \pm 0$ & $54 \pm 2$ & $95 \pm 12$ & Lys & 36 & 190 & 52 & 149 & 264 \\
\hline Met & $23 \pm 3$ & $15 \pm 1$ & $38 \pm 1$ & $34 \pm 2$ & SAA & 17 & 155 & 177 & 325 & 413 \\
\hline Phe & $16 \pm 0$ & $69 \pm 1$ & $77 \pm 2$ & $61 \pm 4$ & AAA & 30 & 158 & 341 & 379 & 220 \\
\hline Thr & $47 \pm 2$ & $27 \pm 0$ & $45 \pm 1$ & $50 \pm 3$ & Thr & 18 & 260 & 148 & 251 & 279 \\
\hline Val & $34 \pm 1$ & $40 \pm 1$ & $64 \pm 1$ & $79 \pm 5$ & Val & 31 & 111 & 130 & 206 & 256 \\
\hline
\end{tabular}

*AA: Amino acid. AASP(R): Amino acid scoring pattern (requirement). SAA: Sulfur containing amino acids; the joint contents of Met and Cys were taken into account. AAA: Aromatic amino acids; the joint contents of Phe and Tyr were taken into account.

This article is protected by copyright. All rights reserved 


\section{FIGURE CAPTIONS}

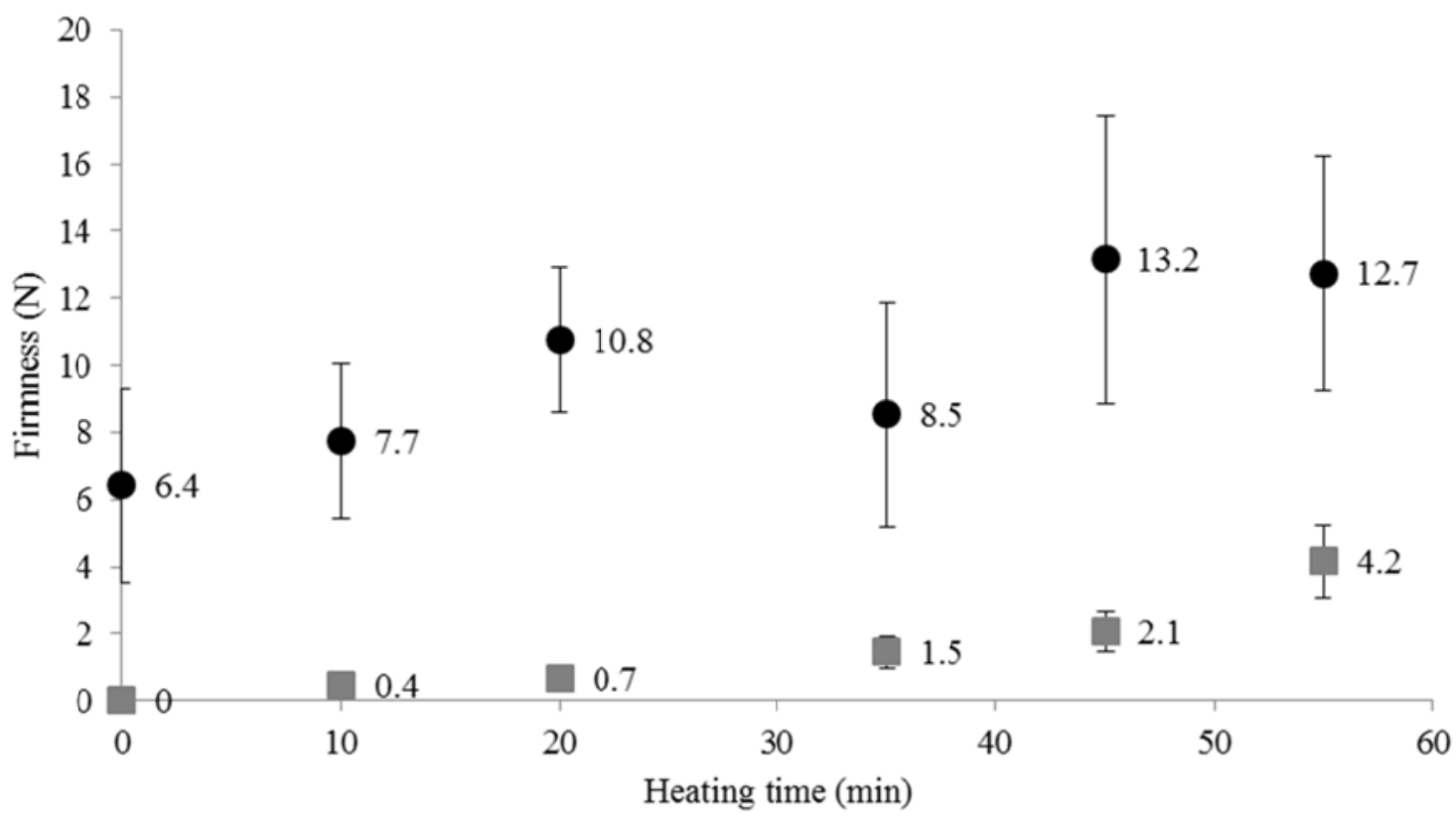

Figure 1. Firmness $(\mathrm{N})$ of wheat gluten blend $(\boldsymbol{\bullet})$ and chicken breast muscle $(\bullet)$ as a function of heating $\left(100{ }^{\circ} \mathrm{C}\right)$ time, measured as the force needed to compress a sample to $40 \%$ of the initial sample thickness.

This article is protected by copyright. All rights reserved 


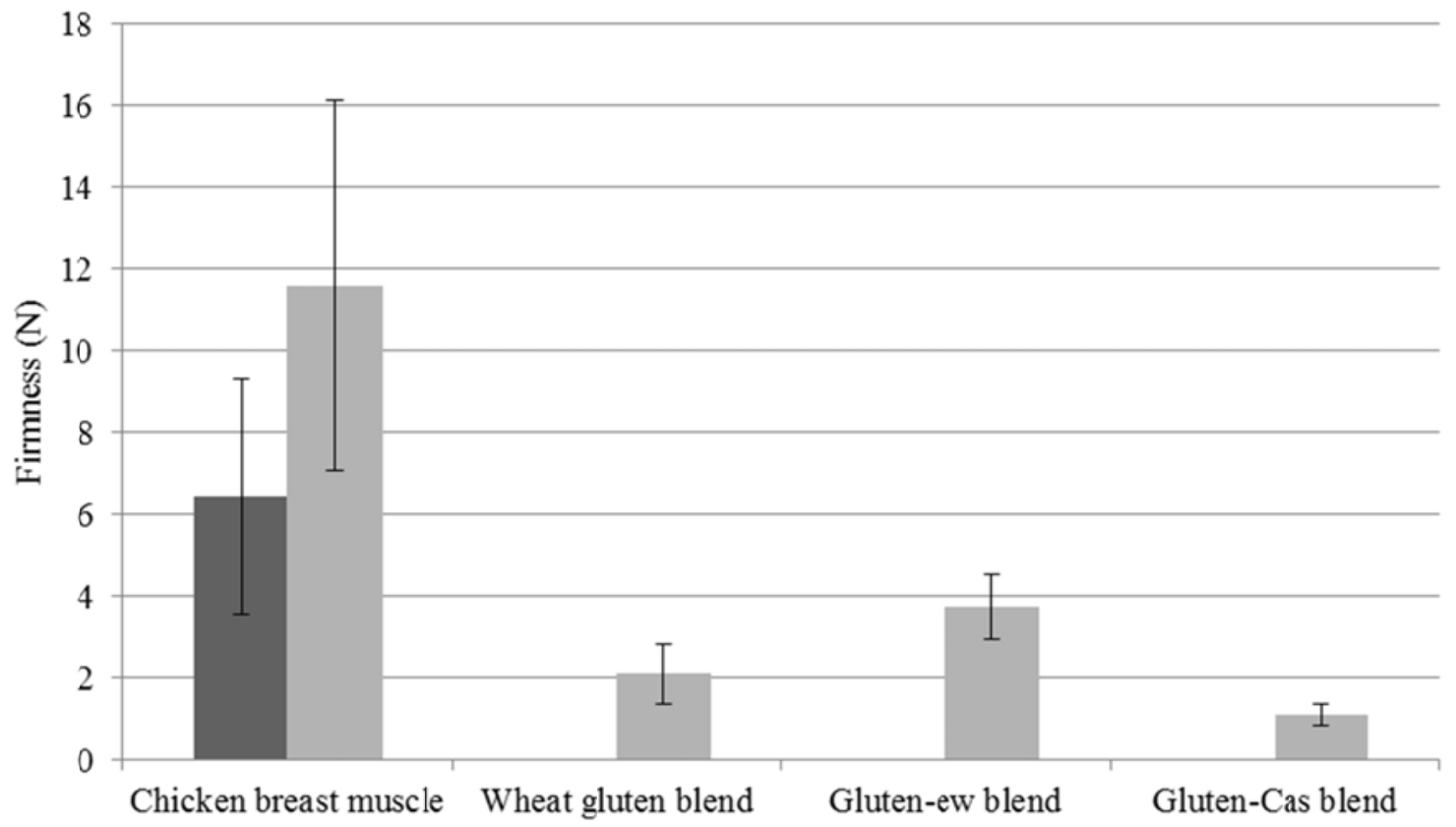

Figure 2. Firmness $(\mathrm{N})$ of chicken breast muscle, wheat gluten blend, gluten-ew blend and gluten-cas blend before (dark grey) and after heating for 120 minutes at $100{ }^{\circ} \mathrm{C}$ (light grey), measured as the force needed to compress a sample to $40 \%$ of the initial sample thickness. 

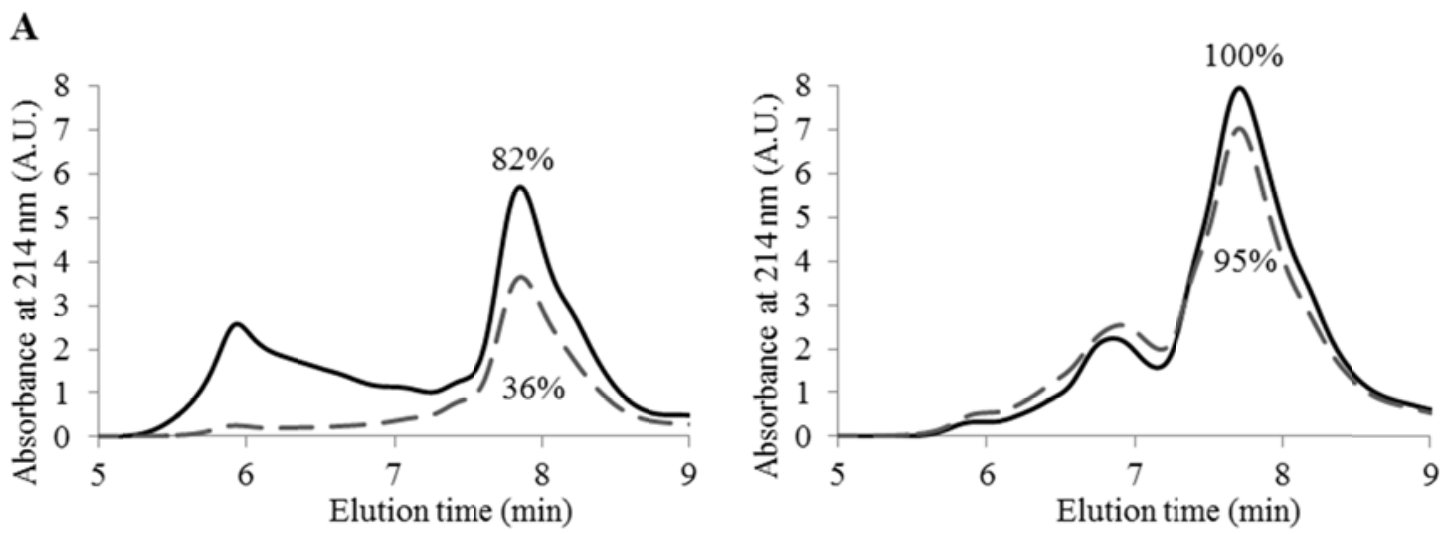

B
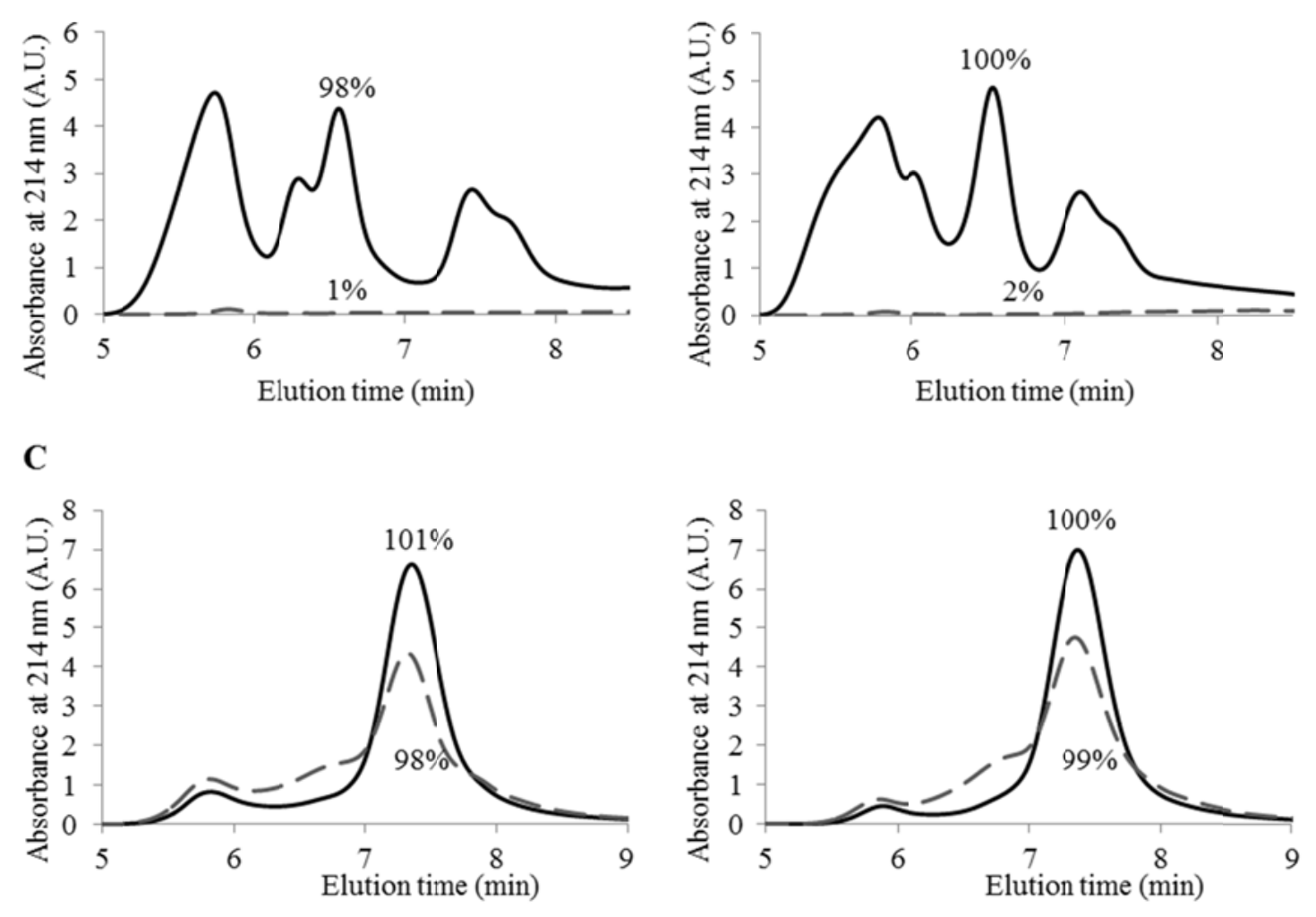

Figure 3. SE-HPLC chromatograms of (A) wheat gluten, (B) egg white proteins, (C) casein under non reducing (Left) and reducing (Right) conditions before (full line) and after (dotted line) heating $\left(120 \mathrm{~min}, 100{ }^{\circ} \mathrm{C}\right)$. Protein extractabilities in SDS containing buffer (SDSEP), calculated as described above, are reported above or below each chromatogram. A.U. are arbitrary units. 